\title{
組紐状高強度繊維補強材を用いたコンクリート梁の 曲げひびわれ性状

\author{
FLEXURAL CRACK BEHAVIOUR OF CONCRETE BEAMS REINFORCED \\ WITH BRAIDED HIGH-STRENGTH FIBRE RODS
}

\author{
谷垣正治*, 野村設 郎**, 岡本 直 ${ }^{* * *}$, 蓮尾孝一**** \\ Masaharu TANIGAKI, Setsuro NOMURA, Tadashi OKAMOTO and Koichi HASUO
}

\begin{abstract}
Application of high-strength fibre rods as reinforcement for concrete structures in order to improve durability, strength, and electromagnetic characteristic is actively studied.

In this paper, the authors examine the flexural crack behaviour of concrete specimens reinforced with braided carbon fibre rods or braided aramid fibre rods subjected to uniaxial tension and flexure. The test results demonstrated that the method to estimate the maximum crack width as proposed for steel reinforcement could be applied to the fibre rods, if the average strain of fibre rods considering tension stiffening effect and the average crack-spacing as a function of the average strain of fibre rods were obtained.
\end{abstract}

Keywords : carbon fibre, aramid fibre, braiding, concrete beam, flexural crack 炭素繊維, アラミド繊維, 組紐状, コンクリート梁, 曲げひびわれ

1.はじめに

一般に，繊維補強材は通常の鉄筋に比較して高強度， 低弾性率であるため，これを曲げ補強筋として用いた梁 では, 終局耐力は高くなるものの初ひびわれ発生後のた わみやひびわれ幅が大きくなるという使用限界状態下で の性能が問題となる場合が多い。これらの問題を解決す るための方法には，より弾性係数の高い繊維素材を用い る方法あるいはプレストレスを導入する方法等が考えら れる。前者の方法において, 主筋として用いる繊維補強 材に求められる主な構造的性能としては, 梁の曲げ耐力 を確保するための「強度」, ひびわれ後のたわみを抑制 するための「剛性」およびひびわれ幅制御にかかわる「付 着性能」が挙げられる。後者の方法は主筋の剛性不足を プレストレスによって補おうとするもので, PRC (Partially Prestressed Concrete) の考え方に基づいて いる。この場合，プレストレスカの役割は，たわみおよ びひびわれ幅の低減，言い換えるならば主筋ひずみの抑 制であり,主筋として用いる瀻維補強材の役割としては, 「強度」ならびにひびわれ幅制御にかかわる「付着性能」
が挙げられる。したがって，いずれの方法においても， 曲げひびわれに及ぼす主筋の影響を把握しておくこと は，このような瀻維補強材を用いるうえで重要である。 また，繊維補強材は錆びないことがその特長の 1 つとし て挙げられるが, ひびわれ幅の制御は, 補強筋の防錆と いう観点からだけでなく, 構造物の美観, 水密性等の確 保という観点からも重要である。

鉄筋を用いた場合のひびわれ幅評価については，既に 数多くの算定式が提案されているが，瀻維補強材は鉄筋 と異なる弾性係数，付着特性を持っているので，これら の提案式を繊維補強材を用いた場合に準用するには問題 があると考えられる。そこで本論では, 組紐状繊維補強 材を対象にし，これまで筆者らが行った両引き付着試験 ならびに梁の曲げ試験の結果に基づき，以下の項目につ いて検討することを目的とした。

1）鉄筋を主筋として用いた梁と対比することにより， 曲げひびわれ性状に及ぼす主筋繊維補強材の影響ならび にその特性を把握する。

2）瀻維補強材を主筋として用いたコンクリート梁に,

\footnotetext{
本論文の一部は文献 13）に既に発表されている。

* 三井建設技術研究所 主任研究員

** 東京理科大学理工学部建築学科 教授・工博

*** 三井建設技術開発推進部 主席研究員

**** 三井建設技術研究所 研究員
}

Technical Research Lab. Mitsui Construction

Prof., Dept. of Architecture, Faculty of Engineering Science Univ. of Tokyo, Dr. Eng.

Research and Developement Dept. Mitsui Construction Technical Research Lab. Mitsui Construction 
既往のひびわれ偪算定手法を適用する場合の問題点の把 握とその補正方法に関する基礎資料を得る。

なお，繊維補強材を用いた部材のひびわれ幅制御設計 にあたって，その制御目標值の設定はひびわれ幅評価と 同様に重要であるが，ここでは，ひびわれ幅評価につい ての検討にしぼり，ひびわれ幅制御目標値設定の問題に ついては検討対象としていない。

\section{2. 既往のひびわれ幅算定式}

ひびわれ偪は, 補強材の伸びとコンクリートの伸びの 差として生ずるので，（1）式に示すように，ひびわれ 間の補強材の平均ひずみ $\left(\varepsilon_{\text {rav }}\right)$ とコンクリートの平均 ひずみ $\left(\varepsilon_{c a v}\right)$ の差とひびわれ間隔 $\left(l_{a v}\right)$ との積で与え られる。図一1に示すように，補強材ひずみはひびわれ 発生位置で最大となり，ひびわれ間のコンクリートの拘 束作用により中央で最小となる。したがって補強材の平 均ひずみ $\left(\varepsilon_{\text {rav }}\right)$ は $(2)$ 式に示されるように，ひびわ れ断面位置での補強材ひずみ $\left(\varepsilon_{r \max }\right)$ とコンクリート の拘束作用による補強材ひずみの減少量 $\left(\Delta \varepsilon_{r}\right)$ の差に よって表される。

$$
\begin{aligned}
& W_{a v}=l_{a v} \cdot\left(\varepsilon_{r a v}-\varepsilon_{c a v}\right) \\
& \varepsilon_{\text {rav }}=\varepsilon_{\text {max }}-\Delta \varepsilon_{r} \\
& W_{\max }=a \cdot W_{a v} \\
& W_{\max }=l_{\max } \cdot\left(\varepsilon_{r a v}-\varepsilon_{c a v}\right)
\end{aligned}
$$

(プレストレスの作用している断面において は，主筋位置のコンクリートひずみが 0 とな る状態 (Decompression) からのひずみ)

$\varepsilon_{c a v}$ :ひびわれ間コンクリートの平均ひずみ

$\varepsilon_{r \max }$ :ひびわれ断面での補強材のひずみ

$\Delta \varepsilon_{r}$ : ひびわれ間コンクリートの拘束作用による補 強材ひずみの減少量

$W_{\max }$ : 最大ひびわれ幅

$a$ : 最大ひびわれ幅と平均ひびわれ幅の比

$l_{\max }$ : 最大ひびわれ間隔

設計上問題となるのはひびわれ幅の最大値（ $\left.W_{\max }\right)$

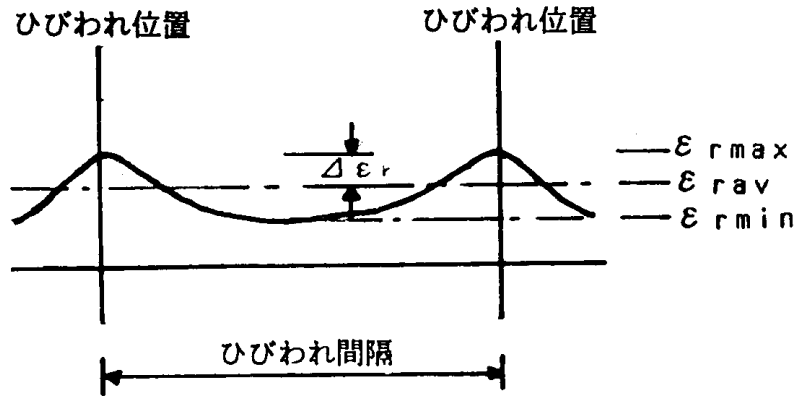

図一1ひびわれ間の補強材ひずみの分布形状
であるが，これを求める方法としては，ひびわれ間隔の 平均值 $\left(l_{a v}\right)$ を用いて $(1)$ 式より平均ひびわれ幅 $\left(W_{a v}\right)$ を求め, それに定数を乗じて ( $(3)$ 式) 算定する方法と, 最大ひびわれ幅 $\left(l_{\max }\right)$ を求めて $(4)$ 式より直接最大 ひびわれ幅 $\left(W_{\max }\right)$ を算定する方法とがある。前者の 方法は森田 ${ }^{1)}$, CEP-FIP Model Code 1978 ${ }^{21}$, 鈴木ら ${ }^{3)}$, 日本建築学会「プレストレスト鉄筋コンクリート（而種 PC) 構造設計・施工指針・同解説」) (以下, PRC 指針 と略記）によって提案されており，（3）式の係数 $a$ と して 1.4 1.7 が用いられている。平均ひびわれ間隔 $\left(l_{a v}\right)$ の算定式には，例えば PRC 指針 ${ }^{4}$ では（5）式 が用いられている。後者の方法は角田 ${ }^{5)}$, ACI 318-83 ${ }^{6)}$, 土木学会コンクリート標準示方書 ${ }^{7)}$, CEB-FIP Model Code $1990^{8)}$ によって示されており，最大ひびわれ幅 $\left(l_{\max }\right)$ の算定式としては，たとえば（6）式皇が挙げ られる。

$$
\begin{aligned}
& l_{a v}=2(c+0.1 s)+0.1 \phi / p_{e} \\
& l_{\max }=k \cdot A_{c e}^{1-\alpha} \cdot c^{\beta} \cdot \phi^{\gamma-1} \\
& c: \text { が湿 (図一2参照) } \\
& s \text { : 補強材間隔（図一 } 2 \text { 参照） } \\
& \phi: \text { 補強材径 (図一2 参照) } \\
& p_{e}: A_{r} / A_{c e} \\
& A_{r} \text { : 補強材断面積 } \\
& A_{c e} \text { : 引張コンクリート有効断面積（図一2 参照） } \\
& k, \alpha, \beta, \gamma: \text { 実験定数 }
\end{aligned}
$$

(6) 式では補強材間隔（s）が考慮されていないと いう相違があるものの, かぶり厚 $(c)$, 補強材径 $(\phi)$, コンクリートの有効断面積 $\left(A_{c e}\right)$ 等考慮されているパ ラメータは, 基本的には各提案式に共通している。また, いずれの方法においても，原則的にはひびわれ定常状態 (荷重が増大しても新たな曲げひびわれが発生しなくな る状態）を対象とし，ひびわれ定常状態の補強材応力が 十分に大きいことを考虑して（1）（4）式中のひびわ れ間コンクリートの平均伸びひずみ $\left(\varepsilon_{\text {cav }}\right)$ を無視して いる。

一般に，ひびわれ定常状態に達する時の平均鉄筋応力 度は $2000 \mathrm{kgf} / \mathrm{cm}^{2}$ 程度, ひずみ度で $1.0 \times 10^{-3}$ 程度で あるが，PRC 梁では，より広範囲な鉄筋応力度で設計 されるため, 定常状態での平均ひびわれ間隔 $\left(l_{a v}\right)$ を

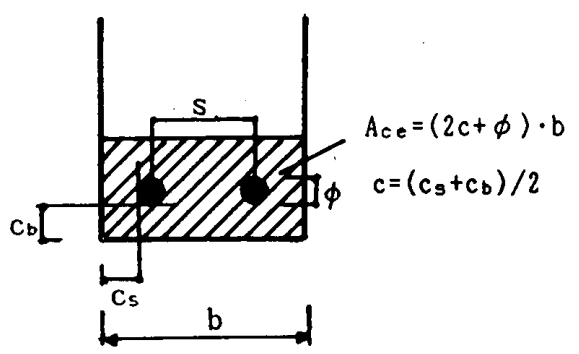

図一2 記 号 
用いた方法ではひびわれ幅を過大に評価してしまうこと が指摘されている3)。

\section{3. 組紐状織維補強材}

本実験に用いた繊維補強材は，アラミド瀻維または炭 素緎維を組紐状に編み，エポキシ樹脂で硬化させたもの である。写真一1, 表一1 に組紐状繊維補強材の形状お よび諸元を示す。写真一1に示すように，繊維を組紐状 に編むことにより表面に規則的な凹凸が形成される。補 強材名称の先頭文字の「K」はアラミド瀻維を「C」は 炭素瀻維を表し，末尾に「S」が付いている補強材には， 組紐状表面に硅砂が接着されていることを表す。アラミ ド瀻維補強材, 炭素瀻維補強材ともに弾性材料であり, その弹性係数はそれぞれ $0.6 \sim 0.65 \times 10^{6}\left(\mathrm{kgf} / \mathrm{cm}^{2}\right)$, $0.9 \sim 1.1 \times 10^{6}\left(\mathrm{kgf} / \mathrm{cm}^{2}\right)$ である。なお，表一1に示す 補強材断面積および弾性係数は，樹脂を含めた補強材の 全断面積より求めた。

\section{4. 試験体および試験方法}

本論でデータとして用いた試験体の一覧を表一 2 に， 試験体断面と加力方法の概略を表一3に示す。シリーズ $\mathrm{A}, \mathrm{B}$ の試験体は，正方形断面のコンクリートプリズム の中心に配置した補強材の両端に軸方向引張力を加える 両引き試験体，シリーズ $\mathrm{C} \sim \mathrm{G}$ の試験体は，長方形断 面およびT型断面の RC（補強コンクリート：瀻維補強 材を用いる場合と鉄筋を用いる場合を併せてここでは $\mathrm{RC}$ と略する）および $\mathrm{PRC}$ 単純梁で，対称二点集中一

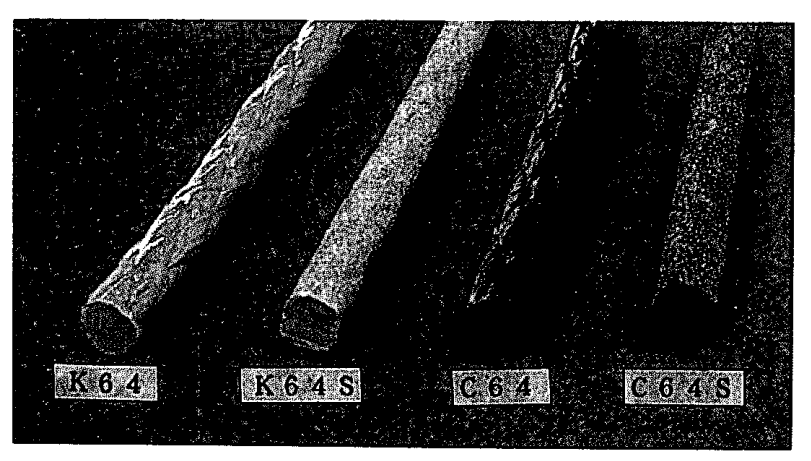

写真一1 組紐状繊維補強材

表一1 組紐状繊維補強材の諸元

\begin{tabular}{|c|c|c|c|c|c|c|}
\hline 棒材名 & 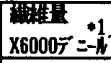 & $\begin{array}{c}\text { 最大直经 } \\
\text { (矂) }\end{array}$ & $\begin{array}{c}\text { 䉼面称 } \\
\left(\mathrm{ma}^{2}\right)\end{array}$ & $\begin{array}{c}\text { 周 長 } \\
\text { (m) }\end{array}$ & $\begin{array}{r}\text { 彈理係 } \\
\times 10^{\circ}\left(\mathrm{kgf} / \mathrm{cm}^{2}\right)\end{array}$ & 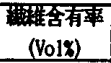 \\
\hline K64 & 64 & $\begin{array}{r}8.0 \\
\text { (9. of }\end{array}$ & 50 & $\begin{array}{c}25.0 \\
(28.0)\end{array}$ & \multirow{5}{*}{$\begin{array}{l}0.61 \\
0.65\end{array}$} & \multirow{7}{*}{$\fallingdotseq 60$} \\
\hline K 96 & 96 & $\left.\begin{array}{rrr}1 & 0.0 & 0 \\
(1 & 1 & 0\end{array}\right)$ & 75 & $\begin{array}{r}31.0 \\
(35.0) \\
\end{array}$ & & \\
\hline K 128 & 128 & $\begin{array}{c}12.0 \\
(13.0)\end{array}$ & 100 & $\begin{array}{r}38.0 \\
(42.0)\end{array}$ & & \\
\hline K 192 & 192 & $\begin{array}{r}14.0 \\
(15.5)\end{array}$ & 150 & $\begin{array}{r}44.0 \\
(49.0)\end{array}$ & & \\
\hline K256 & 256 & $\begin{array}{r}16.0 \\
(17.5) \\
\end{array}$ & 200 & $\begin{array}{r}50.0 \\
(55.0)\end{array}$ & & \\
\hline C 64 & 57 & $\begin{array}{l}8.0 \\
(9.0)\end{array}$ & 50 & $\begin{array}{c}25.0 \\
(28.0)\end{array}$ & \multirow{2}{*}{$\begin{array}{l}0.90 \\
1.10 \\
1.10\end{array}$} & \\
\hline C 128 & 114 & $\begin{array}{c}12.0 \\
(13.5) \\
(13 .\end{array}$ & 100 & $\begin{array}{r}38.0 \\
(42.0)\end{array}$ & & \\
\hline
\end{tabular}

方向載荷の曲げ試験を行ったものであり，試験体の総数 は 75 である。シリーズ A，Bでは，補強材の繊維の種 類 (アラミド, 炭素), 表面状態 (組紐状, 組紐状+硅砂), 補強材径を実験パラメータとした。シリーズ C，D は 主に炭素繊維を用いた武験体であり，補強量および補強 材の表面状態（組紐状, 組紐状十硅砂）を実験パラメー 夕とした。シリーズ E，F，Gに用いた繊維補強材はす ベてアラミド䋞維であり，主筋およびプレテンション緊 張材として用いる場合には組紐状表面に硅砂を接着させ たもの，ポストテンション緊張材として用いる場合には 組紐状のものを使用している。シリーズ E，F では補 強量およびプレストレスカの大きさを実験パラメータと した。比較のために主筋に異形鉄筋を用いた試験体につ いても実験を行った。鉄筋を用いたものは，シリーズA の $\mathrm{AD} 10$, シリーズCの TS-1 およびシリーズ Fの全試 験体である。なお，シリーズ $\mathrm{A} ， \mathrm{~B}$ の試験体は屋内気 中養生，その他はすべて屋外気中養生したものである。 補強材のひずみは, 補強材の表面に貼付したひずみゲー ジ（検長 $2 \mathrm{~mm}$ ) で, ひびわれ幅の測定は, シリーズ $\mathrm{A}$, B ではパイ型変位計 (検長 $50 \mathrm{~mm}$, 精度約 $1000 \mu / \mathrm{mm}$ ), シリーズCではクラックスケール，その他は主筋高さ位 置の梁側面に設けたパイ型変位計（検長 $150 \mathrm{~mm}$, 精度 約 $1000 \mu / \mathrm{mm}$ ) によって行った。

\section{5. 実験結果および考察}

\section{1 ひびわれ測定結果の概要}

図一3に主筋に硅砂を接着させたアラミド瀻維補強材 を用いた F-26-0 試験体（シリーズE）と異形鉄筋を用 いた F-59 S-0 L 試験体（シリーズF）のひびわれ発生 状況を示す。梁の中央たわみが $\mathrm{L} / 100$ の時のひびわれ 状況は両者ほぼ同様であるが，ひびわれ定常状態（純曲 げ区間内で新たな曲げひびわれが発生しなくなる状態) に達する時のたわみは，F-59 S-0 L では L/500 程度で あるのに対し，F-26-0では L/200 程度と差が見られる。

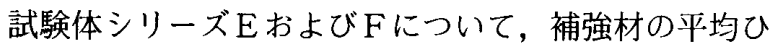
ずみ $\left(\varepsilon_{r a v}\right)$ と平均ひびわれ幅 $\left(W_{a v}\right)$, 平均ひびわれ間 隔（lav $)$ の関係の例を図一 4 に示す。図一 $4 \mathrm{a} ）$ は硅砂 を接着させたアラミド繊維補強材を主筋に用いた場合, 図一 4 b) は異形鉄筋 (D 16) を主筋に用いた場合であり, 緊張材には，ともに硅砂を接着させていないアラミド繊 維補強材を用いている。プレストレス力のある試験体に ついては, 横軸の $\varepsilon_{\text {rav }}$ の值を Decompression 時からの 主筋ひずみの変化量で表している。図一4の○印は実測 された平均ひびわれ幅, 実線は実測された平均ひびわれ 間隔に補強材の平均ひずみを乗じたものである。すべて の試験体について $(7)$ 式の関係がほぼ成り立っており, 瀻維補強材を用いた場合でも，鉄筋を用いた場合上同様 に, ひびわれ定常状態非定常状態にかかわらず， $W_{a v}$ を 
表一2 試験体一覧

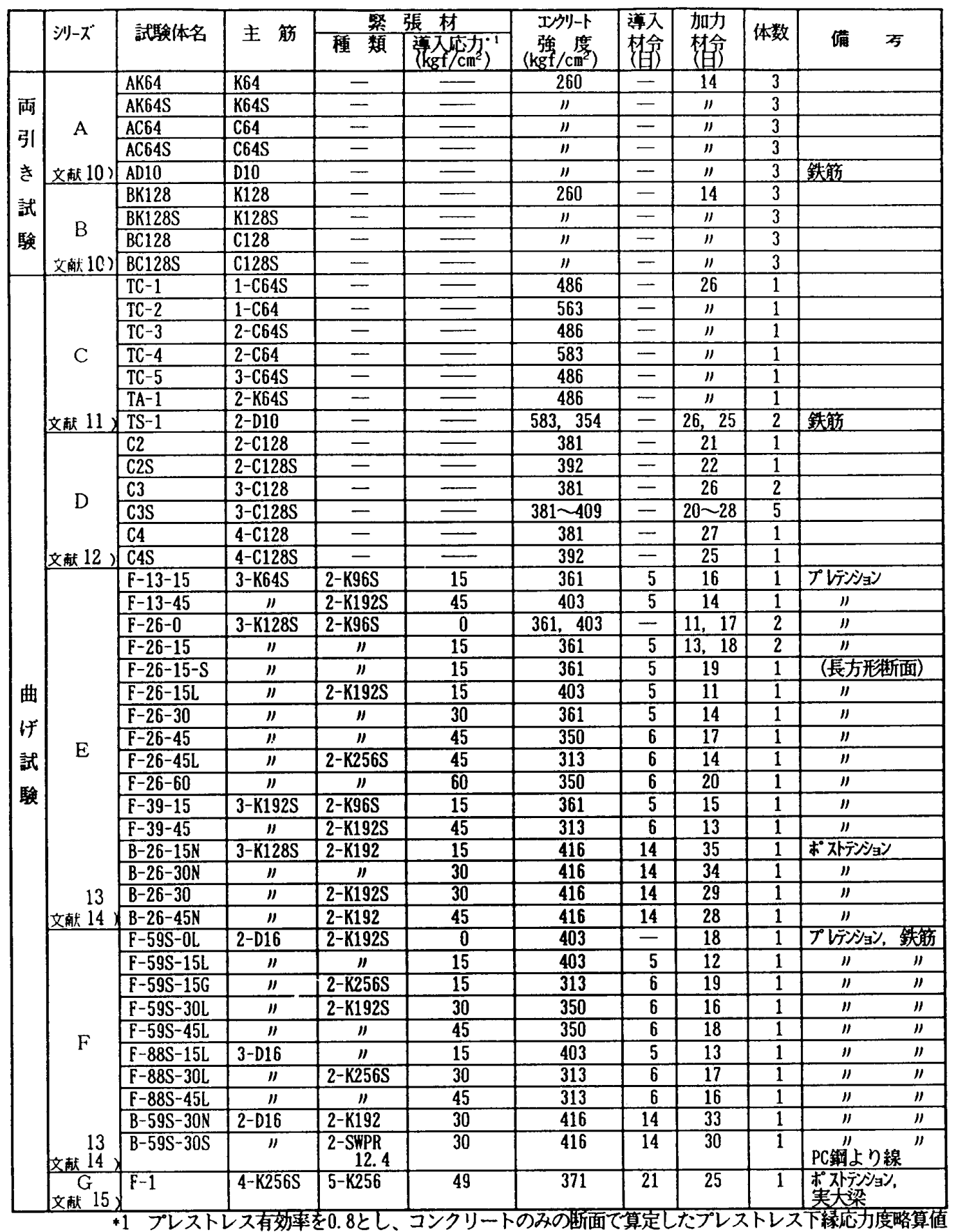

表一3 試験体断面および加力方法

\begin{tabular}{|c|c|c|c|c|c|c|}
\hline シリーズ & A & B & C & $\mathrm{D}$ & $E, F$ & G \\
\hline $\begin{array}{c}\text { 略断面 } \\
\left(\begin{array}{l}\text { 主笳 } \\
\text { ○緊張材 }\end{array}\right)\end{array}$ & $\therefore[\underbrace{\square}_{50}$ & $\therefore[\underbrace{[5}_{L}$ & 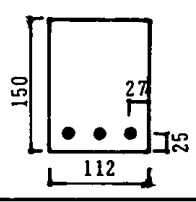 & 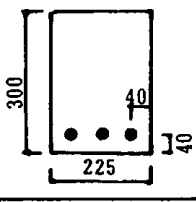 & 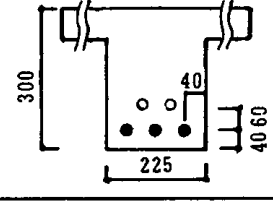 & 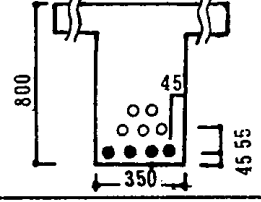 \\
\hline 加力方法 & $\mathrm{L}_{1}=600 \mathrm{~mm}$ & $\mathrm{~L}_{1}=900 \mathrm{~mm}$ & $\begin{array}{l}\mathrm{L}_{1}=1500 \mathrm{~mm} \\
\mathrm{~L}_{2}=375 \mathrm{~mm}\end{array}$ & $\begin{array}{l}\mathrm{L}_{1}=3000 \mathrm{~mm} \\
\mathrm{~L}_{2}=750 \mathrm{~mm}\end{array}$ & $\begin{array}{l}\mathrm{L}_{1}=3000 \mathrm{~mm} \\
\mathrm{~L}_{2}=750 \mathrm{~mm}\end{array}$ & $\begin{array}{l}L_{1}=9600 \mathrm{~mm} \\
L_{2}=1920 \mathrm{~mm}\end{array}$ \\
\hline
\end{tabular}




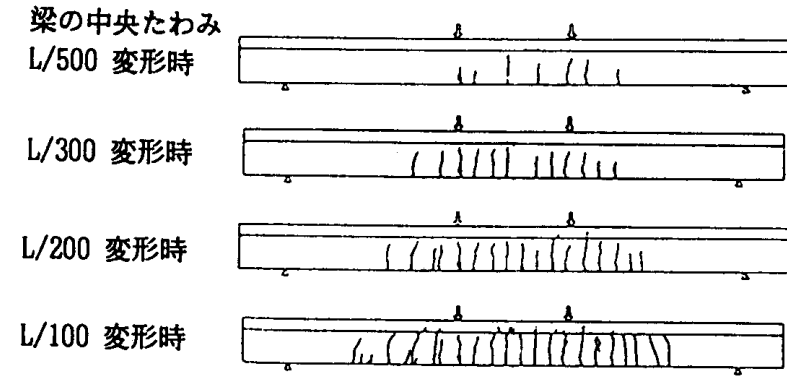

a） F-26-0試験体（アラミド繊維砂付き）

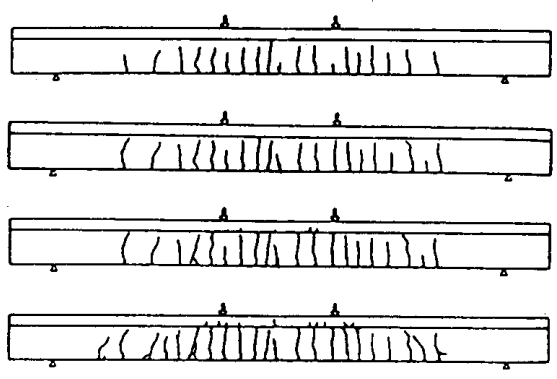

b) F-59S-0L試験体（異形鉄筋）

図一3 ひびわれ発生状況の例

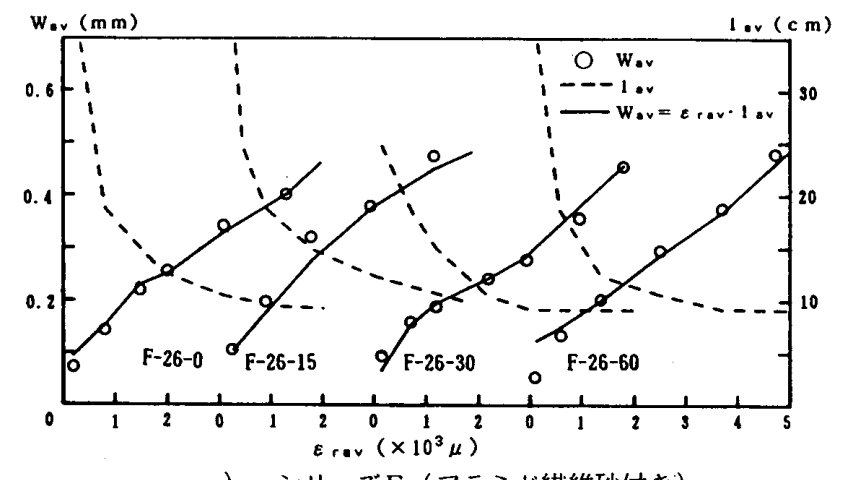

a) シリーズE（ア.ラミド繊維砂付き）

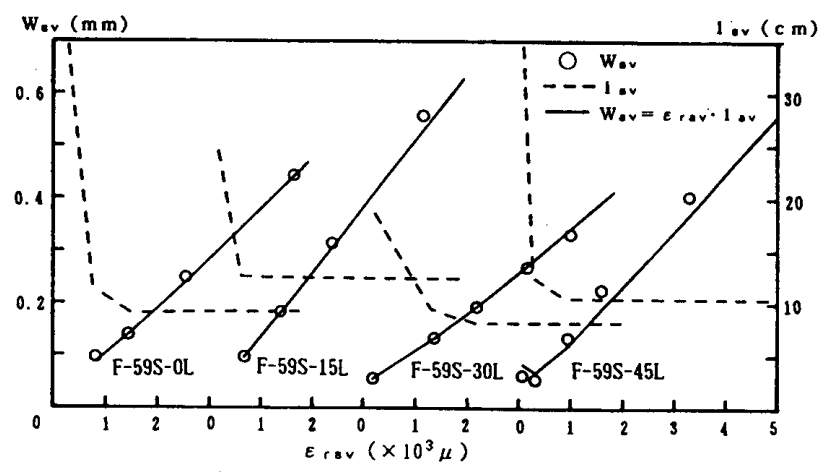

b ） シリー-ズF（異形鉄筋 D16）

図一4 補強材の平均ひずみと平均ひびわれ幅, 平均ひびわれ間隔の関係

（７）式で評価できるものと考えられる。

$$
W_{a v}=l_{a v} \cdot \varepsilon_{r a v}
$$

ひびわれ定常状態における，平均ひびわれ間隔 $\left(l_{a v}\right)$ は，すべての試験体について $10 \mathrm{~cm}$ 前後であるが，主 筋に鉄筋を用いた場合（図一 $4 \mathrm{~b}))$ では補強材の平均ひ ずみ $\left(\varepsilon_{\text {rav }}\right)$ が 1.0 - $1.5 \times 10^{-3}$ でひびわれ定常状態に達 するのに対し，繊維補強材（図一 $4 \mathrm{a}))$ では，ひびわれ 定常状態に達する時の補強材の平均ひずみ $\left(\varepsilon_{\text {rav }}\right)$ は, $3.0 \sim 5.0 \times 10^{-3}$ ときわめて大きい。ひびわれ幅制御設 計において問題となる補強材の平均ひずみ $\left(\varepsilon_{\text {rav }}\right)$ が $1.0 \times 10^{-3}$ 前後であることを考虑すると,このような瀻 維補強材を用いた梁では，ひびわれ非定常状態での評価 が必要であると考えられる。

\section{2 補強材の平均ひずみ}

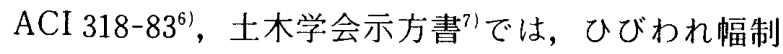
御設計を，ひびわれ定常状態を対象に行うことを前提と しており，ひびわれ定常状態での鉄筋応力度が大きいこ とならびに設計上安全側の評価であるという理由から， コンクリートの拘束作用による鉄筋ひずみの減少量 $\left(\Delta \varepsilon_{r}:(2)\right.$ 式）を無視している。鈴木ら ${ }^{31}$ は, PRC 梁においては鉄筋比が RC に比べ小さく，使用状態下 での鉄筋ひずみも低めに設計されるために，コンクリ一 トの拘束作用を無視するとひびわれ幅が過大に算定され ることを指摘している。コンクリートの拘束作用は, 補 強材の剛性が低いほど大きく, 纎維補強材の上うに弾性 係数の低い材料を用いた場合に，コンクリート拘束作用
を無視すると，ひびわれ幅やたわみを過大に算定するこ とになり，設計上非常に不利になる。したがって，緎維 補強材を用いるに際し，コンクリートの拘束作用を把握 しておくことは，鉄筋を用いた場合以上に重要であると 考えられる。

六車ら ${ }^{16)}$ は, $(8)$ 式に示される付着応力の分布形に よって定まる係数 $k_{1}$ 亡，（9）式によって示されるコン クリート部の引張強さに対する補強材負担力の変化量の 比 $k_{2}$ を用い, (10) 式に示す $k_{1} k_{2}$ によって, コンクリー トの拘束作用を評価する方法を提案し，実験結果よりコ ンクリート強度ならびに鉄筋の種類（異形鉄筋，丸鋼） にかかわらず，気中養生の場合（11）式が成り立つこと を示した。またPRC 指針 ${ }^{41}$ では，同様の形式の算定式

(12) 式が提案されている。

$$
\begin{aligned}
& \sigma_{r \max }-\sigma_{r a v}=k_{1}\left(\sigma_{r \max }-\sigma_{r \min }\right) \cdots \cdots \\
& A_{r}\left(\sigma_{r \max }-\sigma_{r \min }\right)=k_{2} A_{c e} \sigma_{t B} \cdots \cdots \\
& k_{1} k_{2}=\frac{A_{r}}{A_{c e} \sigma_{t B}}\left(\sigma_{r \max }-\sigma_{r a v}\right) \cdots \cdots \cdots \\
& k_{1} k_{2}=-\frac{1}{2.2 \times 10^{3} \varepsilon_{r a v}+1.1}+0.22 \\
& k_{1} k_{2}=\frac{1}{2.0 \times 10^{3} \varepsilon_{r a v}+0.8} \cdots \cdots \cdots \cdots \\
& k_{1} k_{2}=\frac{a_{3}}{a_{1} \varepsilon_{r a v}}+a_{2}
\end{aligned}
$$
ここ

$\sigma_{r \max }$ :ひびわれ位置で生ずる補強材の最大忍力度 
$\sigma_{\text {rav }}:$ 補強材の平均応力度

$\sigma_{r \min }$ :ひびわれ間で生ずる補強材の最小応力度

$A_{r}:$ 補強材断面積

$A_{c e}$ : 引張コンクリートの有効断面積 (図一2 参照)

$\varepsilon_{\text {rav }}$ : 補強材の平均ひずみ

繊維補強材に対するコンクリートの拘束作用を把握す るために，曲げ材の引張部を模擬したコンクリートプリ ズムの一軸両引き試験（シリーズ A，B）を行い，引張 荷重ならびに供試体全長の軸方向伸びから，(10）式に 示す方法によって， $k_{1} k_{2}$ を求めた。その結果を図一 $\left.5 \mathrm{a}\right)$ ～d）に示す。図一 $5 \mathrm{e}$ ）は比較のために行った異形鉄筋 （D 10）の結果であり，図中に（11），(12）式を示す。 供試体数が 3 体と少なく，結果もあるバラツキを有して いるので（11），(12）式の適合性は論じ難いが，(12） 式の方がより安全側の值を与えている。ここでは，(12) 式の一般形として (13) 式を設定し，繊維補強材を用い た場合の実験結果から(13) 式の係数 $a_{1}, a_{2}$ を回帰した。 その結果を図一 $5 \mathrm{a}) \sim \mathrm{d})$ に示し，各回帰式を比較して 図一 $5 \mathrm{f})$ に示す。ここではコンクリートの引張強度時 のひずみを $0.1 \times 10^{-3}$ とし，その時の $k_{1} k_{2}$ を 1.0 とし ているので, (13) 式中の $a_{3}$ は $a_{3}=a_{1} \times 10^{-4}+a_{2}$ となる。 硅砂を付着させていないアラミド瀻維（図一 $5 \mathrm{a}$ )) では データにバラツキが見られるが，回帰曲線を見る限りで は，硅砂接着による表面状態の改質が $k_{1} k_{2}$ に及ぼす影 響よりも，補強材の弹性係数の差の影響の方が大きいよ うである。補強材弾性係数の低いものほど $k_{1} k_{2}$ は大き $\sigma_{t B}:$ コンクリートの引張強度

くなっており，このことは，補強材剛性（断面積 $\times$ 弾性 係数）の低いものほ上゙コンクリートの拘束作用が得られ やすいという一般的認識と合致する。

ただし，ここではコンクリートの拘束作用を表す指標 として $k_{1} k_{2}$ を用いたが， $k_{1} k_{2}$ は (10) 式に示されるよ うにひびわれ位置で生ずる最大応力度 $\left(\sigma_{r \max }\right)$ と平均 応力度 $\left(\sigma_{\text {rav }}\right)$ との応力度差を表すものである。したがっ て，図一 $5 \mathrm{f})$ では，図一6に示すように同一の平均補強 材ひずみ $\left(\varepsilon_{\text {rav }}\right)$ が生じているときの応力度差 $\left(\Delta \sigma_{F}, \Delta \sigma_{s}\right)$ の大小を比較していることになる。種々の弾性係数を持 つ材料に対するコンクリート拘束作用を比較評価できる 方法を考案することが, 今後の課題と考えられる。

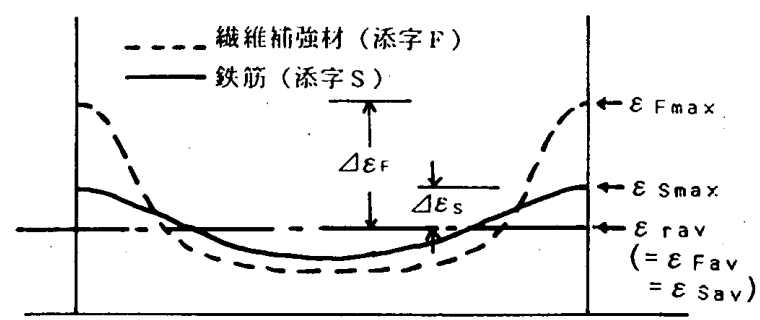

a）ひずみによる比較

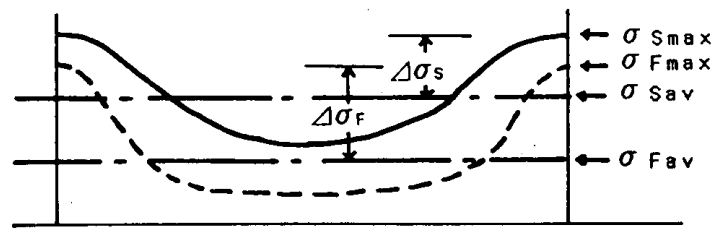

b ）応力度による比較

図一6ひびわれ間の補強材ひずみ・応力度の分布
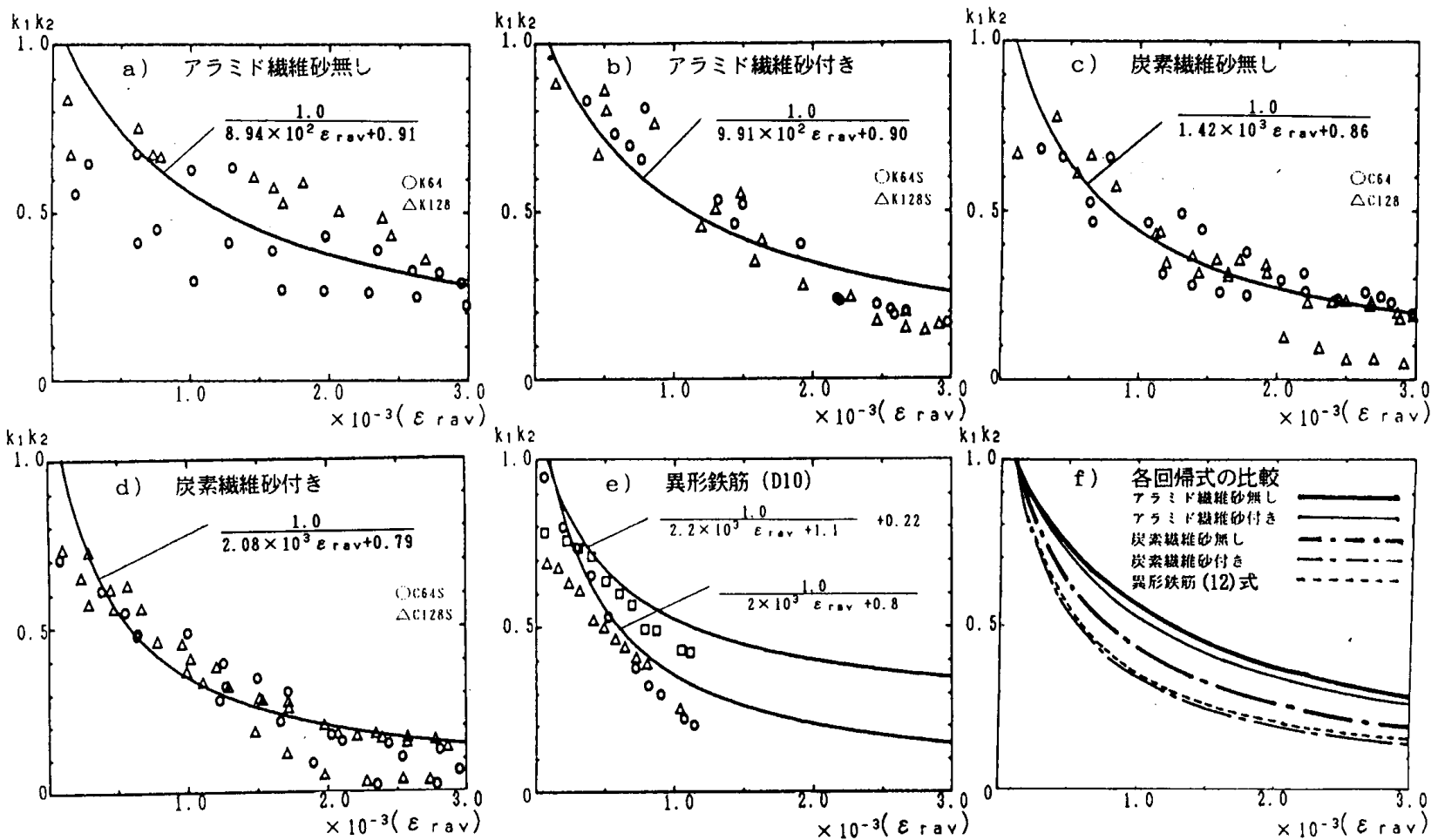

図一5 $k_{1} k_{2}$ と補強材の平均ひずみの関係 


\section{3 平均ひびわれ間隔 $\left(l_{a v}\right)$}

(1) （3）式の方法によって最大ひびわれ幅 $\left(\boldsymbol{W}_{\max }\right)$ を算定する場合には，平均ひびわれ間隔 $\left(l_{a v}\right)$ を求め る必要がある。平均ひびわれ間隔算定式の一般形は (14) 式に示すように，かぶり厚 $(c)$ と補強材間隔 $(s)$ に かかわる第 1 項と補強材の径 $(\phi)$, 断面積 $\left(A_{r}\right)$ およ び引張コンクリートの有効断面積 $\left(A_{c e}\right)$ にかかわる第 2 項とから構成されている。

$$
\begin{aligned}
& l_{a v}=a_{4}\left(c+a_{5} s\right)+a_{6} \phi / p e \\
& l_{a v}=2(c+0.1 s)+a_{6} \phi / p e
\end{aligned}
$$

(記号は（5）式参照)

この算定式の物理的意味を鈴木ら ${ }^{171}$ は，次のように説 明している。(14）式第 2 項は，図一7 a）に示すように, 補強材とコンクリートの付着応力をひびわれ断面位置か ら補強材に沿って合計した值が，その断面コンクリート の引張強度に対応する断面引張荷重に達するまでの距離 $\left(l_{1}\right)$ を，(14）式第 1 項は, 図一7 b ) に示すように第 2 項による応力が，コンクリート断面内にほぼ一様にか つひびわれを発生させるに十分な引張応力となって分布 するまでの距離 $\left(l_{2}\right)$ を表している。この解釈に従えば, 繊維補強材を用いた場合においても，かぶり厚 $(c)$ お よび補強材間隔 $(s)$ にかかわる第 1 項の係数 $a_{4}, a_{5}$ に ついては, 鉄筋についての既往の研究によって得られた 值を用いることが可能である。また，この係数 $a_{4}, a_{5}$ はひびわれ定常状態非定常状態のいかんにかかわらず一 定であると考えられる。したがって, 繊維補強材を用い た場合の平均ひびわれ間隔算定の基本式として（15）式 を設定した。前述したように，繊維補強材を用いた場合

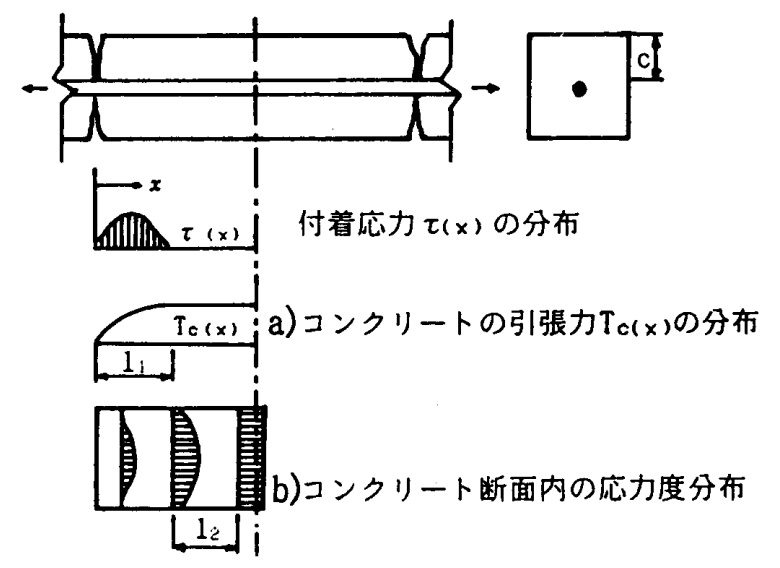

図一7ひびわれのメカニズム17)

では, ひびわれ非定常状態におけるひびわれ間隔を評価 する必要がある。そこで（16）式に示すように，補強材 の付着性能にかかわる係数 $a_{6}$ を補強材の平均ひずみ $\left(\varepsilon_{\text {rav }}\right)$ の関数として与え, この式の係数 $b_{1}, b_{2}, b_{3}$ を 実験值の回帰によって求めた。その結果を図一 $8 \mathrm{a}$ ) 〜 e) に示す。図一8f) は図一 $8 \mathrm{a}$ ) －e）の各回帰曲線を比較 したものである。補強材の平均ひずみ $\left(\varepsilon_{r a v}\right)$ の増加に 伴う $a_{6}$ の娍少傾向は, 補強材弾性係数が高いほどまた 表面に硅砂を接着させたものほど強くなる。特に，硅砂 接着によるひびわれ分散効果は顕著である。このことは, 表面状態の改質によって， $l_{1}($ 図一7 a )) が短くなった ことを意味する。

$$
a_{6}=\frac{b_{3}}{b_{1} \varepsilon_{r a v}+b_{2}}
$$

ここでは実験から得られた $l_{a v} よ り （ 15 ）$ 式を用いて
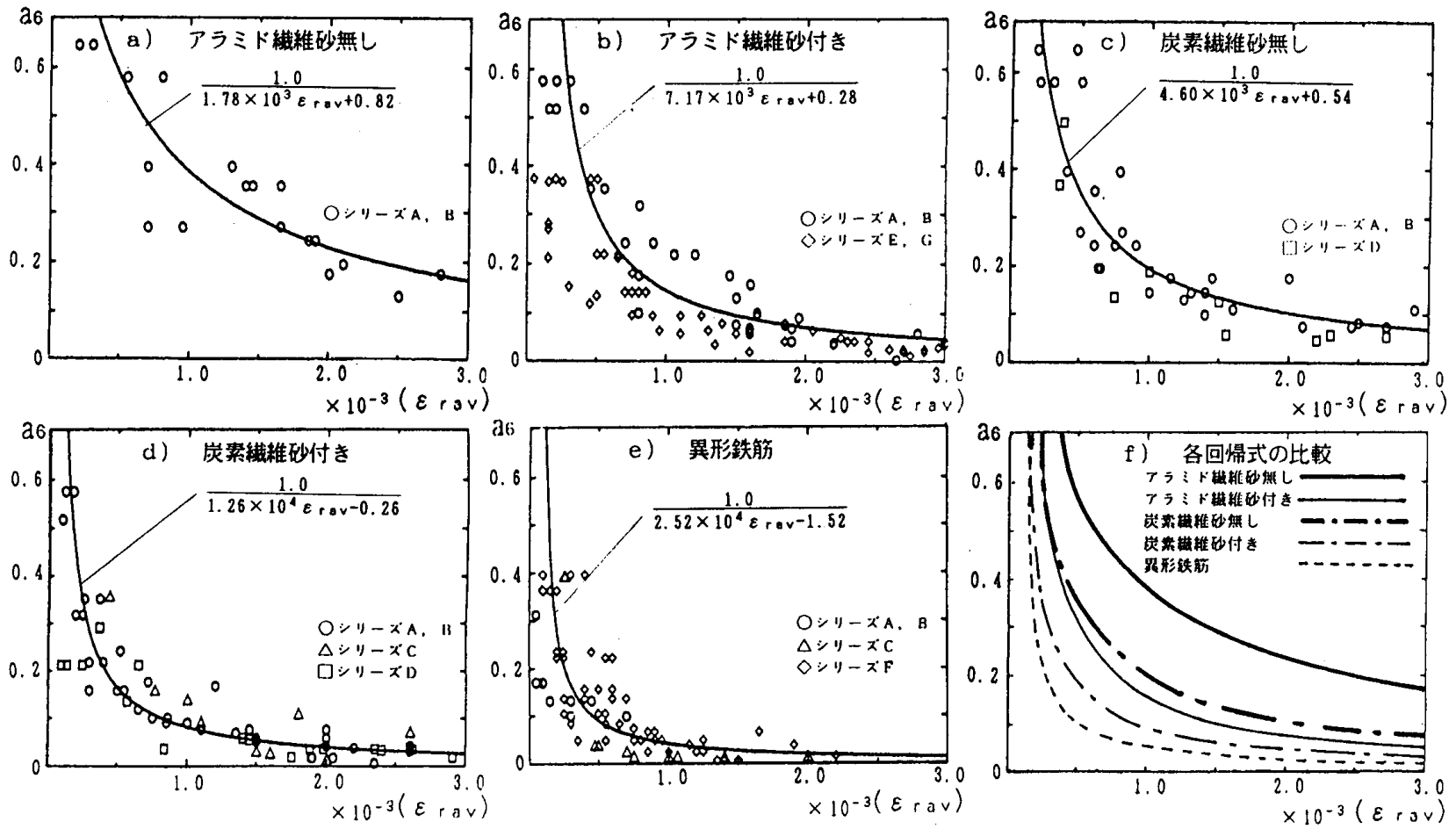

図一8 平均ひびわれ間隔算定式における係数 $a_{6}$ 之補強材の平均ひするみの関係 
$a_{6}$ を求めているが，すべての実験值において $a_{6}$ は負の 値をとっておらず， $l_{a v}$ は（15）式第 1 項 $2(c+0.1 s)$ を下回ることはなかった。したがって，(15）式第 1 項 を補強材の種類ならびにひびわれ定常状態非定常状態に かかわらず一定とした仮定は，少なくとも過大な評価を 与えるものではないと考えられる。

\section{4 最大ひびわれ幅 $\left(W_{\max }\right)$}

ここでは，(1)〜（ 3 ）式の方法によって最大ひびわ れ幅を算定することを前提として，平均ひびわれ幅 $\left(W_{a v}\right)$ と最大ひびわれ幅 $\left(W_{\max }\right)$ の関係を求めた。そ の結果を図一9に示す。鈴木ら³は，鉄筋を用いた $\mathrm{RC}$ ， $\mathrm{PRC}$ 梁の実験結果に基づき, 主筋応力度 $3000 \mathrm{kgf} / \mathrm{cm}^{2}$ 以下の範囲で最大ひびわれ幅 $\left(W_{\max }\right)$ 亡平均ひびわれ 幅 $\left(W_{a v}\right)$ の比 (( 3$)$ 式の係数 $\left.a\right)$ が 1.4 1.5 であるこ とを示しており，これらの研究を受けて PRC 指針 ‘゙ は，(17）式が提案されている。

本実験で用いた䋐維補強材の場合（図一9a)～c)）に ついても使用繊維の種類, 表面状態の差違, プレストレ ス力の大きさにかかわらず（17）式の関係が成立すると 考えられる。また，この関係はひびわれ幅の小さな段階 から, 平均ひびわれ幅 $\left(W_{a v}\right)$ で $0.6 \mathrm{~mm}$ 以上, 補強材 の平均ひずみ $\left(\varepsilon_{\text {rav }}\right)$ にして $3.0 \times 10^{-3}$ 以上の非常に大 きなひびわれ幅まで成り立っている。したがって，䋐維 補強材を用いた場合でも（17）式によって最大ひびわれ 幅を推定し得るものと考えられる。

$$
W_{\max }=1.5 W_{a v}
$$

\section{5 ひびわれ幅算定法のまとめ}

$k_{1} k_{2}-\varepsilon_{\text {rav }}$ 関係が図一 5 のごとく求まれば，任意の荷 重が作用した時のコンクリート引張抵抗を無視した断面 の補強材応力度 $\left(\sigma_{r \max }\right)$ を用いて, (18) 式より補強材の 平均ひずみ $\left(\varepsilon_{\text {rav }}\right)$ をもとめことができる。

$$
\varepsilon_{\text {rav }}=\frac{1}{E_{r}}\left(\sigma_{r \max }-k_{1} k_{2} \frac{\sigma_{t B}}{p_{e}}\right)
$$

$E_{r}:$ 補強材の弾性係数

さらに， $a_{6}-\varepsilon_{\text {rav }}$ 関係が図一 8 のごとく求まれば，平 均ひびわれ間隔 $\left(l_{a v}\right)$ は，(15) 式によって求められる。 このようにして得られた $\varepsilon_{r a v}, l_{a v} よ り$, 平均ひびわれ 幅 $\left(\boldsymbol{W}_{a v}\right)$ は $(7)$ 式で, 次いで最大ひびわれ幅 $\left(\boldsymbol{W}_{\max }\right)$ は

(17) 式によって求めることができる。 $k_{1} k_{2}-\varepsilon_{\text {rav }}$ 関係 が補強材の表面状態にかかわらず弾性係数のみによって 決まると考えれば，図一5の実験結果を参照することに よって任意の弾性係数の補強材に対する $k_{1} k_{2}-\varepsilon_{\text {rav }}$ 関 係を推定し得ると考えられる。ただし，図一 8 に示す $a_{6}$ - $\varepsilon_{\text {rav }}$ 関係は，ここで用いた組紐状瀻維補強材に対する 実験結果であるので，任意の補強材に対して適用するた めには, 今後実験データの蓄積が必要と考えられる。

なお，(18）式では，曲げ材の引張域をコンクリート 断面 $A_{c e}$ を持つ一軸引張状態に置換できると仮定してい るが，中立軸位置の低い段階すなわち補強材ひずみの小 さな段階では，この仮定は必ずしも妥当でないと考えら れる。したがって, 補強材ひずみの小さな段階において, コンクリートの拘束作用を過大に評価しないための制限
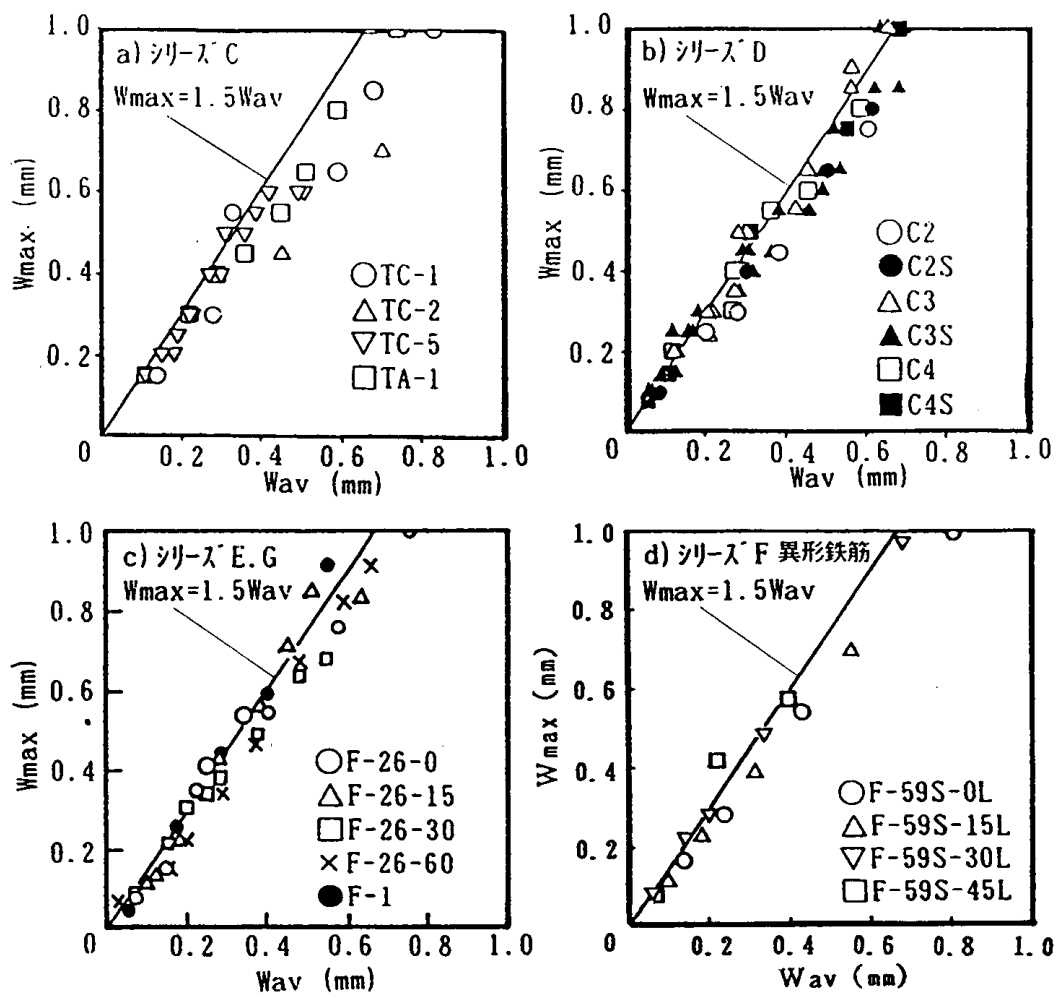

図一-9 平均ひびわれ幅と最大ひびわれ幅の関係 
が必要である17)。このような制限として，例えば PRC 指針)では下式を設定している。

$$
\varepsilon_{r a v} \geqq 0.4 \sigma_{r \max } / E_{r}
$$

\section{6. まとめ}

高強度瀻維補強材をコンクリートの補強筋に用いるた めの基礎的な段階として, 使用状態下で問題となる曲げ ひびわれ性状に着目し，組紐状炭素瀻維補強材ならびに 組紐状アラミド繊維補強材を用いた $\mathrm{RC}, \mathrm{PRC}$ 試験体 の両引き試験, 曲げ試験に基づいて, 主筋緎維補強材の 曲げひびわれに及ぼす影響について検討した。実験結果 および考察から得られた事柄を以下にまとめる。

1) 平均ひびわれ幅 $\left(W_{a v}\right)$ と平均ひびわれ間隔 $\left(l_{a v}\right)$ 補強材の平均ひずみ $\left(\varepsilon_{r a v}\right)$ の関係 $W_{a v}=l_{a v} \cdot \varepsilon_{r a v}$ は，緎 維補強材を用いた場合にも成立する。

2）繊維補強材を用いた場合，ひびわれ定常状態（荷重 が増大しても新たな曲げひびわれが発生しなくなる状 態）に達するときの補強材の平均ひずみは 3.0 ～ $5.0 \times$ $10^{-3}$ 程度と大きいので, 平均ひびわれ幅, 補強材の平 均ひずみともに，ひびわれ非定常状態での評価が必要で ある。

3）ひびわれ非定常状態における平均ひびわれ間隔 $\left(l_{a v}\right)$ は，同一の補強材ひずみで比較すると，繊維補 強材の弾性係数の高いものほ亡゙，また補強材表面に硅砂 を接着させたものほぼ，小さくなる。特に，硅砂接着に よるひびわれ分散効果は顕著である。

4）ひびわれ間コンクリートの拘束作用による組紐状繊 維補強材応力の減少量は, 同一の補強材ひずみで比較す ると，弾性係数の高い補強材ほよ゙，多くなるが，硅砂の 接着による影響はあまり見られない。

5）組紐状繊維補強材を用いた梁の最大ひびわれ幅 $\left(W_{\max }\right)$ は，通常の鉄筋を用いたときと同様，平均ひ びわれ幅 $\left(\boldsymbol{W}_{a v}\right)$ の約 1.5 倍である。

6）補強材の平均ひずみ $\left(\varepsilon_{\text {rav }}\right)$ は, (13) 式に示す $k_{1} k_{2}$ - $\varepsilon_{\text {rav }}$ 関係が図-5のごとく求まれば，(19）式の条件 の下で (18) 式を解いて求められる。平均ひびわれ間隔 $\left(l_{a v}\right)$ は，(16) 式に示す $a_{6}-\varepsilon_{\text {rav }}$ 関係が図-8のごよく 求まれば，(15）式より求めることができる。 $\varepsilon_{\text {rav }}$ およ び $l_{a v}$ から，既往のひびわれ幅算定法と同様に，（７) 式によって平均ひびわれ幅が，(17）式によって最大ひ びわれ幅が求められる。

最後に，今後の課題としては，異なる弾性係数を持つ 補強材のコンクリート拘束作用を比較評価する方法の検 討が挙げられる。また，任意の弾性係数，表面形状を持 つ補強材に対するひびわれ非定常状態におけるひびわれ 間隔を推定するためには，今後実験データの蓄積が必要 であろう。

\section{謝 辞}

本論文を作成するにあたり，貴重なご助言を賜わった 早稲田大学理工学部建築学科谷資信教授, ならびに貴重 な実験データをご提供頂いた東海大学工学部建築学科永 坂具也教授に深く感謝致します。また，本論文を作成す るにあたりご協力頂いたアイシーエス小坂田諭氏，なら びに試験体製作にご協力頂いた神鋼鋼線工業（株）の関 係各位に深く感謝致します。

\section{参考文献}

1）森田司郎；コンクリートのひびわれ幅制限で決まる鉄筋 の許容応力度，七メント技術年報，XXII，1969

2) CEB-FIP ; CEB-FIP Model Code 1978

3）鈴木計夫，大野義照；プレストレスト鉄筋コンクリート 梁の曲げひびわれ幅に関する研究一その 1 . 初期ひびわ れ幅について一，日本建築学会論文報告集，第 303 号, pp. 9 19, 昭和 56 年

4）日本建築学会; プレストレスト鉄筋コンクリート（四種 PC) 構造設計・施工指針・同解説， 1986

5）角田与史雄;鉄筋コンクリートの最大ひびわれ幅，コンク リートジャーナル, Vol. 8, No. 9, Sept. 1970

6) ACI ; Building Code Reinforced Concrete, ACI 318-83, 1983

7) 土木学会；コンクリート標準示方書（昭和 61 年制定） 1986

8) CEB-FIP ; CEB-FIP Model Code 1990

9）角田与史雄; 曲げを受けるコンクリート部材のひびわれ とたわみに関する研究の現状, 土木学会論文集, 第 384 号, V-7, pp. 29 40, 1987

10）蓮尾孝一, 岡本 直; 谷垣正治;アラミド緎維による組 紐状棒材の研究（その12. 付着性状 II, 両引き付着試験 結果)，日本建築学会大学学術講演梗概集 C, pp. 991 992,1990 年 10 月

11）永坂具也，近藤 悟; 組紐状瀻維棒を補強材とするコン クリート梁の曲げ挙動に関する基礎的研究，日本建築学 会大会学術講演梗概集 C,pp. 971 972，1990 年 10 月

12）永坂具也, 近藤 悟; 組紐状炭素繊維補強材で補強され たコンクリート梁の曲げ挙動に関する実験的研究，コン クリート工学年次論文報告集，12-1，pp. 1105 1110, 1990

13）岡本 直, 遠藤克彦, 松原澄行, 谷垣正治; アラミド䋐 維による組紐状棒材を用いた PRC 梁の曲げ性状, 構造 工学論文集, Vol. 35 B, pp. 219 230, 1989

14）谷垣正治, 野村設郎, 岡本 直, 遠藤克彦;組紐状 AFRP ロッドを用いた PRC 梁の曲げ性状, コンクリート工学 年次論文報告集, $11-1$, pp. 801 806, 1990

15）谷垣正治，野村設郎，岡本 直，遠藤克彦; 組紐状 AFRP ロッドを用いた実大 PRC 梁の曲げ性状，コンク リート工学年次論文報告集, 12-1, pp. 1093 1098, 1990

16）六車 熙，森田司郎；鋼とコンクリートの付着に関する 基礎的研究（II．鉄筋コンクリート引張材の変形につい て), 日本建築学会論文報告集, 第 134 号, pp. 1 8, 昭 和 42 年 
17）鈴木計夫, 大野義照; PRC 部材の曲げひびわれ幅算定法, プレストレストコンクリート, Vol.24, No.1, Jan. 1982

18) Suri, K. M., Dilger, W. H. ; Crack Width of Partially Prestressed Concrete Member, ACI Journal, pp.784 795, Sep.-Oct., 1986

19) Tanigaki, M., Okamoto, T., Endo, K.; Flexural Behaviour of Concrete Beams Reinforced with Braided
High Strength Fibre Rods, FIP XIth Congress Hamburg, Vol.2, pp. T 78 T 81, 1990 June

20）谷垣正治, 野村設郎, 岡本 直, 遠藤克彦; 組紐状アラ ミド繊維補強材を用いた PRC 梁の曲げ性状に関する実 験的研究, 日本建築学会構造系論文報告集, 第 420 号, pp. 31 41, 1991

(1990 年 11 月 9 日原稿受理, 1991 年 6 月 14 日採用決定) 